\title{
STRATEGIC BUYER SATISFACTION: A PROBLEM OF COMMUNICATION, COMMITMENT AND CONFLICT RESOLVE
}

\author{
Gatut L. Budiono \\ Pasca sarjana Universitas Pancasila, Jakarta \\ Email: gatutbudiono@gmail.com
}

\begin{abstract}
This study had been referred to the results of research of Selnes (1996), Sumarto et al (2012), about antecendents and consequences of trust and satisfaction in buyer-seller relationships. Primary data and correlational method were incorporated. Commitment of the seller strongly associated with customer satisfaction, the better the commitment of the seller was increasing customer satisfaction. Communication seller strongly associated with satisfaction of the buyer, the better sellers communicate has increased customer satisfaction. Strong problem solving related to customer satisfaction, the better the settlement of the problem by sellers has increased customer satisfaction.
\end{abstract}

Keywords: Satisfaction, commitment, communication, conflict resolve

Abstrak: Penelitian ini telah didasari hasil penelitian Selnes (1996), Sumarto et al(2012), sekitar antecendents dan konsekuensi dari kepercayaan dan kepuasan dalam hubungan pembeli dan penjual. Data yang digunakan adalah data primer dan metode korelasional. Komitmen dari penjual sangat terkait dengan kepuasan pelanggan, semakin baik komitmen penjual dapat meningkatkan kepuasan pelanggan. komunikasi penjual sangat terkait dengan kepuasan pembeli, penjual yang dapat berkomunikasi dengan baik dapat meningkat kepuasan pelanggan. Pemecahan masalah yang baik terkait dengan kepuasan pelanggan, lebih baik penyelesaian masalah dengan penjual telah meningkatan kepuasan pelanggan.

Kata kunci: Satisfaction, commitment, communication, conflict resolve

\section{INTRODUCTION}

The cohesion of buyers and sellers have often raised by researchers on the relationship of the seller and the buyer in the marketing of such opinion of Aijo (1996), Biong and Selnes (1995) Palmatier, (2008) has drawn the attention of both Researchers and practitioners to the role of marketing within relationships, building relationships buyers and sellers was through relationship marketing. Understanding the relationship the buyer and seller must understand beforehand the relationship marketing.

Relationship marketing involves customer relationship with the seller, relationship marketing was an important part should be fostered by every company, such a statement (Grönroos, 1994), (Surujlal et al, 2012) the purpose of relationship marketing was to establish, maintain and Enhance relationship with customers at a profit. Relationship marketing was intended to build, maintain and improve customer relations. Relationship marketing was an effort to improve customer relationships with suppliers.

Relationship marketing was a long-term profitable relationship, as the opinion of the (Graf et al, 2011) that relationship marketing involves a dynamic process with continuity 
as an important objective. The relationship between the buyer and seller were formed in the long term, such as the principle of (Berry, 1983) and (Grönroos, 1994) (Narayandas and Rangan, 2004) (Walz, 2009) (Konhauser, 2007) whom were stated that the acknowledgment exchanges between buyers and sellers to an increasing extent take place within long term relationships. Relationship marketing has a long-term relationship must always be nurtured in order to create long-term profitability. Thus marketing relationship includes the relationships between the buyer and supplier was a very important part of every company's need to be noticed.

Relationship marketing has become a continuous dynamic process. The purpose of relationship marketing was improving customer relations. Means there have been more beneficial relationship between buyers and sellers match the opinion (Ravald and Grönroos, 1994) (Mohanty, 2012), that was a mutually profitable relationship for the supplier and buyer. The increase in mutually beneficial relationships between the buyer and supplier depends on the activity of exchange value and the value of relationships. As in the theory of (Selnes, 1995) (Wang, 2004) that the improvement of relations depends on the ability to provide value and relationship of value episodes continuously.

Customer satisfaction has been the ultimate goal of service suppliers, influenced by three important components include communication, commitment and ability to solve problems by suppliers; these three components greatly affect customer satisfaction, as expressed by (Selnes, 1995) that communication would increase of satisfaction with the supplier, then the proposed commitment would also signaling Increase satisfaction with the supplier and the last of constructive conflict handling will increase of satisfaction with the supplier. Based on this concept, researchers have been interested in examining the relationship of communication, commitment and resolve disputes between sellers and buyers of fish feed in Cianjur.

Research problem identification was: there have been facts ineffective communication of fish supplier, likely to cause disappointment among the buyers of other sub-distributor of fish feed and fish farmers. On the other hand there was lack of clarity commitment of suppliers and did not have the ability to resolve any problems quickly and accurately as well as fun frustrate buyers was increasing. Formulation of research problem was: based on the identification of the problem, the formulation of the problem in the study includes: was there a significant positive relationship between communications, commitment, problem solving with customer satisfaction? The purpose of this study was to determine the relationship between communication, commitment and problem resolution by a supplier to buyer satisfaction fish feed in Cianjur. The benefits of research were: Useful for marketing managers, among other useful information in an effort to improve customer satisfaction through increased communication, commitment and ability to resolve problems in the trade transactions. Further information could be useful as additional information for further research.

Limitations of the research problem was the sale and purchase transaction has been carried out between sellers of fish feed Anggun Pratama CV with buyers of fish feed in Cianjur, West Java. Additionally this study discusses the main ideas of the buyer satisfaction: a problem of communication, commitment and resolve conflict. This study was analyzed the relationship of communication, commitment, and ability to solve problems by producer to consumer satisfaction, so the results may not be generalizable for the purchase of which was outside the district of Cianjur. 


\section{THEORITICAL REVIEW}

There were communications in business interaction practices done by te seller and customer. Customer response as a communication expected by marketers according to (Kotler, 1997:573) (Del Rio et al, 2001) that the marketers could be seeking a cognitive, affective, or behavioral response from the target audience. Marketers want the effective communication with some special effects such as cognitive effects, establish awareness of certain information. Effects of affection, give effect to do something to be expected that the realization of the purchase. Behavioral effects, shaping consumer behavior was expected to re-purchase.

Furthermore, it should be understood about the communication according to (Selnes, 1995:310) (Zeffane et al, 2011) communication was the exchange of information between suppliers and customers; several studies suggest that the exchange of information were an important part of both traditional industrial selling and relationship marketing. Exchange of information between buyers and sellers has been very important for the improvement of relationship marketing. Information would be able to provide awareness and understanding among buyers and sellers, which capable of satisfy and establish a mutually beneficial relationship. The right information constitute reference for successful communication, an advisor would succeed in communication when capable providing the correct information, as such information constitutes investment communications in easily understandable language. Morgan and Hunt (1994: 158) (Illes et al, 2015) depict an easy flow of communication is an important characteristic of a strong relationship. Chronology of the ease of information is a characteristic of strong trading relationship. Moorman et al., (1993: 157) (Taleghani et al, 2011) illustrates that timely communication establish trust by assisting in resolving disputes and aligning perceptions and expectations.

Communication had also showed whether a communicator qualified technically and functionally, Clark (1992: 24) (Mohammad et al, 2011) illustrated that communication was an important ingredient for achieving high perceived service quality. High communication skills needed to convince the client. Proper communication has made the client managed to find out the status of investments, future opportunities and risks that may be encountered and to know the expected financial returns. Based on these circumstances, the frequency and success of communication form the client's perception of service quality.

The commitment of the seller had become one of the key determinants of the success of relationship marketing, increase customer relationship, it was in accordance with the opinion of (Johansen, 1991: 310) (Wetzels et al, 1998) (Bollen et al, 2008) that the commitment could manifest itself in various ways like making adjustments to standard products or services or by investing in the relationship. Commitment may established any sellers use various ways to adapt to the standards of products and services. Commitment seller was the willingness and ability of sellers to adjust their products to buyers' requirements. Sellers were committed to always flexible to replace items that do not fit the criteria of the buyer. Sellers quickly adapt when there was a change to the buyer.

The dispute resolution should be solving problems of conflict must be done in order to keep the business running and neither party let down. Consumer disappointment has been the loss of business. The conflict had been a negative impact on the relationship between the seller and the buyer if the problem could not be resolved properly by the seller, it was appropriate opinion of (Dwyer, 1987:310) (Miall, 2004) (Fiala, 2012) and (Suryanto T, 2016) that conflict could be destructive, with hostility, bitterness and the 
resulting isolationism. The statement indicates that conflik was not resolved properly could result in disfigurement, destruction and hatred. Consequently reducing the level of customer relations. Conflicts occured due to differences in perception about objectives raised desire of sellers and buyers. Based on this it is certain that the settlement of the conflict has been very influential on buyer satisfaction.

The customer satisfaction was a necessity for the survival of the business relationship. In accordance with (Kotler, 1995:46) (Tolpa, 2012) that customer satisfaction was the outcome felt by buyers who have experienced a company performance that has fulfilled expectations, the sense was expressed also by (Kurt \& Clow, 1998:381) (Giese et al, 2002) that the satisfaction of the state of satisfaction was determined by how counsumers perceived the service they received Compared to what they had expected prior to the service. In general, customer expectations were estimates or beliefs about what customers would receive if they buy goods and services, while the perceived outcome constitute customers' perception of what they received after consuming the product. For that matter management must have the same perception with customers in order to obtain results that exceed or equal to the customer's expectations.

Consumer satisfaction or dissatisfaction according to (Cengiz, 2010) was the result of the evaluation of a spesific transaction or consumption experience defined that satisfaction was the level of a person's felt resulting from comparing a product's perceived performance in relation to the person's expectation. Customer satisfaction with the product and services affected by the expectations of consumers and the quality of services they received, it was as described by (Parasuraman, 1985: 48.

When the dimensions of service quality have already standardized by the company, the factors that affect customer satisfaction depends on the expectations of consumers. If the expectations of consumers vary, the level of customer satisfaction would be different anyway, if the company has been able to provide the same service to every customer, then the customer satisfaction with service companies were not necessarily the same value as another customer, because there were different expectations among customers.

Customer expectations as above could be understood if it was known factors that influence it. According to (Kurtz \& Clow, 1998:70) (Anderson and Liedman, 2013) there were three factors antecedents of consumer expectation, namely: internal factor as in individual needs, level of involvement and past experience. External factor as in competitive options, social context, word of mouth. Firm produced factor as in promotion, price, distribution and communications that affect customer expectations. According to (Kurz \& Clow, 1998:382), if the service performs at the level that was expected or predicted, the satisfaction level was considered to be just "OK", if the service provided was in accordance with expectations, it would give them satisfaction. Thus, if the quality of service could be improved reach the expectations of the customer, and the customer would be satisfied. According to Parasuraman (1985:49) (Mosahab et al, 2010) when satisfactory quality of customer satisfaction approximately equal to the expectation of performance, it means customer satisfaction occurs when there was the same expectations with its performance, thus satisfaction has been influenced by the quality of service.

Satisfaction depends on two factors, namely the expectations of consumers and the quality of service perceived by consumers. This was stated again by (Kurts and Clow, 1998:381) (Salim et al, 2014) the state of satisfaction was determined by how consumers perceived the service they received compared to what they had expected prior to the service. Satisfaction was the comparation between the perceived qualities of consumer to 
consumer expectations, if the perceived quality of consumers under expectations, then the customer was unsatisfied, if the perceived quality of consumers in accordance with the expectations, then the customers were satisfied, and if the quality perceived by the consumer exceeds expectations then the consumer was very satisfied. Based on this understanding, the satisfaction was a function of quality assessed or perceived consumer.

Satisfaction was a function of quality assessed by consumers, it was reminded again by (Kotler, 1995:10) (Lawson and Cox, 2010) if the product's performance falls short of the customer's expectations the buyer was dissatisfied. If performance matches expectations, then the buyer was satisfied. If performance exceeds expectations the buyer was delighted. The element of satisfaction was twofold quality assessed by consumers and the expectations of consumers. The expectations of every customer by (Kurtz and Clow, 1998: 69) (Anic and Radas, 2006) consumer expectations were impacted by an individual's personal philosophy of service, situational factors, and the firm related factors of service personnel, tangible cues of customers, and firm image. Consumer expectations were also influenced by various factors both internal and external, or quality factor of the product itself. While the quality was rated by consumers consist of an assessment of the products, services, personnel and image. These were variables that would determine the level of satisfaction of the consumer. The most important element in consumers' assessment was an assessment of the Quality of Service.

The relationship between communication, commitment and conflicts handling with consumer satisfaction is certainly often the case in business. Businessmen and buyers were people who have a different character and desire each other. Take action to bridge differences, reduces the business conflict was an obligation for the businessman, if not then maybe they would lose customers. As was explained earlier that communication of seller, the seller's commitment and resolve problems that have been performed by the seller would be able to improve customer relationships and the seller (Selnes, 1996: 317) (Senasu, 2012). It was realized that communication, commitment and conflict handling effect on satisfaction in accordance with the statement of (Selnes, 1996:310) communication will increase of satisfaction with the supplier, Signalling commitment will increase of satisfaction with the supplier, constructive conflict handling will increase of satisfaction with the supplier,

According to (Selnes, 1996:310) signaling commitment would increase satisfaction with the supplier, seller who has a strong commitment to adhere to the sales agreement, would be able to increase customer satisfaction (Selnes, 1996:310) commitment has been identified as one of the key characteristics of successful relationships in enhancing the good relationship with the buyer, so that a strong commitment from the seller would be able to improve customer satisfaction. Based on the statement of theories above, hence, the research hypothesis (H1) that has been proposed was there is a relationship between the seller's commitments to customer satisfaction.

Furthermore (Selnes, 1996:310) argues that communication would increase of trust of the supplier, effective communication could improve customer satisfaction (Selnes, 1996:310) communication was expected to be an important source for satisfaction. It could lead to a shared understanding of performance outcomes and expectations. Communication was able to regulate the relationship between the realities of service to consumer expectations. Based on the statement of theories above, the proposed hypothesis (H2) was that there is a relationship between the seller's commitments to customer satisfaction. 
The final statement of (Selnes, 1996:310) was constructive conflict handling would increase satisfaction to the supplier. The ability of suppliers to overcome all the problems greatly influenced the increase of buyer satisfaction. Based on the statement above, hence, the hypotesis $(\mathrm{H} 3)$ of the research proposed that there is a relationship between the seller's conflict handling to customer satisfaction.

Research Framework. To better understand the description could be understood through the following images:

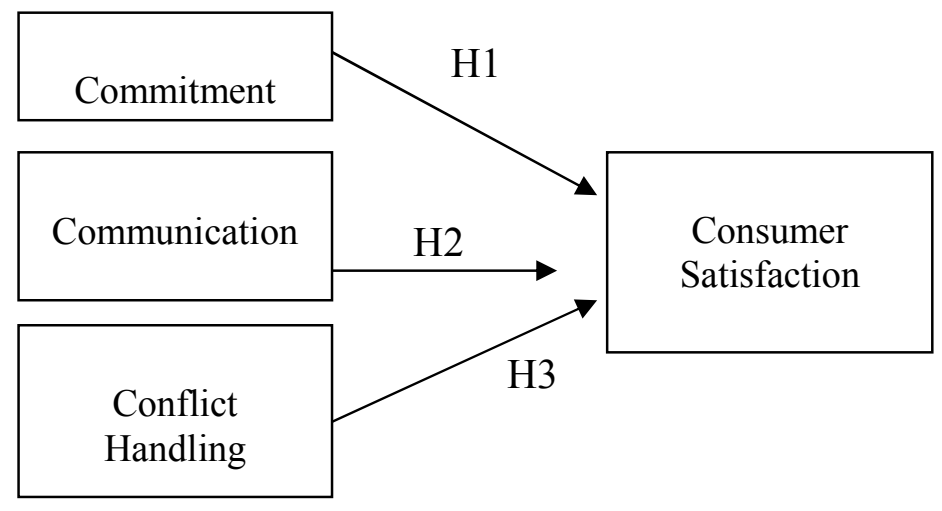

Figure 1, The Research Framework

Figure 1 shows the communication, commitment and conflict handling by suppliers related to customer satisfaction, the better the communication, commitment and conflict handling ability of the seller, will increase buyer satisfaction.

\section{METHODS}

The method of this research was descritive quantitative. This study has been referred to the theory of Selnes (Selnes, 1996: 305-322) in the form of survey, using a questionnaire as a data collection tool. The aim was to test the hypothesized relationship between commitment, communication, problem solving, with customer satisfaction.

Variables and measurement of this study was measured using an instrument (Selnes, 1996) includes four variables, such as supplier commitment (X1), communications suppliers (X2) and the ability of conflict handling by the supplier (X3) and customer satisfaction $(\mathrm{Y})$.

Commitment was measured by the seller to the respondents questions like: suppliers could adapt to the needs of the buyer, could adjust their products to the buyer, it was very flexible when buyers ask for replacement feed products, could adjust to the change orders for goods according to the buyer. Then the respondents were asked to answer based on the 5 -point Likert scale, $1=$ strongly disagree, $2=$ disagree, $3=$ quite agree $4=$ disagree and 5 $=$ strongly agree.

Communication was measured by the question: supplier provides information about product quality, providing an explanation in case of delivery problems, may provide an explanation if there was a problem of quality of goods and explanations given by supplier always conform to state of the amount and quality of goods. 
Conflict handling has been measured by asking questions such as: suppliers enabled better address quality issues and the delivery of goods, was able to convince consumers, able to ensure that no problems will arise in the cooperation of buying and selling, willing and able to bear the risk of any problems that arise, problems can be solved well and relatively quickly.

While the question of customer satisfaction include: consumers are satisfied because the supplier is able to adapt to the needs of the buyer, consumers are satisfied because the supplier can customize the product to the buyer, satisfied that there is flexibility when buyers ask for replacement of product, suppliers can adjust to changes goods orders as buyers desire, suppliers can provide information about the quality of products. Consumers are satisfied because the supplier can provide explanations regarding a problem of delivery, may provide an explanation about a problem of quality of goods, information given by supplier always conform to state of the amount and quality of the goods, the supplier is able to overcome the problem of the quality and delivery of goods, to convince consumers, guarantee of solving problems, cooperative relationship with suppliers. Consumers are satisfied because the supplier is able to bear any risk, is able to resolve the problems with good and relatively quickly.

The sample consisted of $25 \mathrm{sub}$ distributors and 60 farmers. Sample study was 85 , the number of respondents who studied the same with population size. Because the population is less than 100 people, then if the subject was less than 100 people are better taken all (Suharsimi Arikunto, 1996: 120), so that the research was the study of population or census.

Data obtained directly from respondents using questionnaires, in the form of a written questions answered by the respondents to obtain information directly about everything they were felt and knew. Questionnaires were distributed to all respondents and have collected 85 questionnaires returned all amount in accordance to the number of samples planned.

After the data completely collected, checking the completeness of the answers and after the data was completely full and then tested for validity and reliability. The validity test has been conducted using face validity for the use of the instruments belonging to previous researchers (Fred Selnes, 1996) which has been testing the validity earlier, according to Nunnally (Singarimbun, 1995: 128) the validity of the used instruments by previous researchers (Fred Selnes , 1996), means that such instruments have had a high validity because it was consistent with the framework of theoretical concepts and results of previous studies.

Reliability testing has been conducted with Cronbach alpha technique. Calculations using the statistical program SPSS ver. 9.0 has been obtained Cronbach alpha value of variable instruments of commitment, communication and problem-solving by the supplier obtained at $0.7754>0.7$ and Cronbach alpha value of variable instruments buyer satisfaction at $0.8771>0.7$ citing the statement of Nunnaly (Singarimbun, 1995: 123) the research data has been a reliable and worthy to be processed in testing.

Data analysis was using descriptive statistics and analytic (Nana Sudjana 1997: 77) due to more easily managing data, more meaningful and easier to understand in the form of frequency tables, graphs and average value (Nana Sudjana 1997: 77). Analytic statistics used in testing hypotheses to be able to make generalizations sample data on the population. 
The hypothesis test was using p-value was then compared with 0:05 significant value. The hypothesis test was formulated as follows: If the $\mathrm{p}$ value $>0.05$ means Ho is accepted and if the $p$-value $<0.05$ means Ha accepted.

\section{RESULTS AND DISCUSSION}

The respondent has the characteristics of age and sex as follows:

Table 1. Profile of Respondents

\begin{tabular}{|c|c|c|}
\hline No & Profile & Number of people \\
\hline A. & Age & \\
\hline 1. & $20-25$ & 12 \\
\hline 2. & $26-30$ & 19 \\
\hline 3. & $31-35$ & 23 \\
\hline 4. & $36-40$ & 16 \\
\hline 5. & $41-45$ & 9 \\
\hline 6. & $46-50$ & 4 \\
\hline 7. & $>51$ & 2 \\
\hline B. & Sex & \\
\hline 1. & Male & 83 \\
\hline 2. & Female & 2 \\
\hline & Total & 85 \\
\hline
\end{tabular}

The Hypothesis Testing of a Relationship among Commitment, Communication, Problem Solving and Customer Satisfaction.

Table 2. Commitment of Seller

\begin{tabular}{clcc}
\hline No. & \multicolumn{1}{c}{ Seller commitment } & Average & $\begin{array}{c}\text { Standard } \\
\text { Deviation }\end{array}$ \\
\hline 1. & $\begin{array}{l}\text { Supplier adjust to the needs of buyers } \\
\text { 2. }\end{array} \quad \begin{array}{l}\text { Supplier adjusting its products according to the } \\
\text { buyer }\end{array}$ & 4.0824 & 0.5392. \\
3. & $\begin{array}{l}\text { Supplier highly flexible, on demand replacement } \\
\text { of the product }\end{array}$ & 3.6824 & 0.5651 \\
& $\begin{array}{l}\text { Supplier was sable to adjust the desired changes } \\
\text { goods ordered by buyers }\end{array}$ & 4.0706 & 0.4828 \\
& $\quad$ Average & 3.988 & - \\
\hline
\end{tabular}

Table 2 shows the information that best judgment against the seller's commitment was a statement of the supplier can provide the products according to the buyer need with a good average (4.1176), this situation shows that this commitment has the highest level of 
customer satisfaction. While the indicator gives value to the worst service commitments were very flexible supplier statement, when a buyer makes a request replacement of goods with a pretty good average (3.6824). In Table 4 indicated the average value indicator supplier commitments for 4988, indicating that the assessment of the average seller commitment has been good.

Tabel 3. Communication of Seller

\begin{tabular}{clcc}
\hline No. & Seller Communication & Average & $\begin{array}{c}\text { Standard } \\
\text { Deviation }\end{array}$ \\
\hline 1. & $\begin{array}{l}\text { Supplier provides information on quality } \\
\text { products }\end{array}$ & 4.3882 & 0.5140 \\
2. $\quad \begin{array}{l}\text { Supplier explain if there were problems of } \\
\text { shipping goods }\end{array}$ & 4.0941 & 0.5901 \\
3. $\quad \begin{array}{l}\text { Supplier explain if there was any quality } \\
\text { problems }\end{array}$ & 4.1882 & 0.4999 \\
4. $\quad \begin{array}{l}\text { The explanation has been given by the } \\
\text { supplier always correspond with the number } \\
\text { and quality } \\
\text { Rata-rata }\end{array}$ & 4.1176 & 0.4475 \\
\hline
\end{tabular}

Table 3 provides information on the best communication of the supplier was providing information on quality products, with a good average (4.3882), indicating that the communications of supplier has the highest customer satisfaction. While the worst assessment of the supplier was supplier communication to explain the problem of delivery, with the average value of (4.0941). Table 5 also shows the average value of the seller's communications (4.1970), this indicates that the assessment of the average supplier communication is good.

Table 4. Conflict Handling

\begin{tabular}{clrc}
\hline No. & Conflict Handling & Average & Standard Deviation \\
\hline 1. & $\begin{array}{l}\text { Supplier was able to overcome the problem of } \\
\text { the quality and delivery of goods }\end{array}$ & 4.2235 & 0.4191 \\
2. $\quad \begin{array}{l}\text { Supplier was able to convince the customer, do } \\
\text { not have problems of cooperation buyer-supplier } \\
\text { relationships. }\end{array}$ & 4.6588 & 0.5467 \\
3. $\quad \begin{array}{l}\text { Supplier was able to bear the risk of the problem } \\
\text { and relatively fast finish well }\end{array}$ & 4.1765 & 0.4674 \\
& & \\
& Average & 4.3529 & - \\
\hline
\end{tabular}

Table 4 displays the information of greatest value to the settlement of the problem was the supplier able to convince the customer that no problems arise during cooperation relationship with suppliers, worth a good average (4.6588), indicating that the solution of the problem has the highest level of customer satisfaction. While indicators that give the 
lowest ratings are an indicator that states bear the risk of suppliers capable of any problems arise, so that any problems have been completed with good and relatively quickly, worth a good average (4.1765) Table 6 also shows the average value of 4.3529 for conflict handling, this shows that the assessment of the problem averagely was good. Meanwhile, on customer satisfaction, customer satisfaction ratings have been obtained with the average value (4.2588). This information shows that consumers were satisfied with the ways of communication, commitment and problem solving was done by the supplier. The Relationship among Commitment, Communication and Problem Solving with
Consumer Satisfaction

Table 5. Hypothesis Testing Results

\begin{tabular}{lccc}
\hline \multicolumn{1}{c}{ Hypothesis } & Correlation & P-value & Ho \\
\hline $\begin{array}{l}\text { H1: There is a significant relationship between the } \\
\text { seller's commitment to customer satisfaction }\end{array}$ & 0,667 & 0,000 & Rejected \\
$\begin{array}{l}\text { H2: There is a significant relationship between the } \\
\text { seller's communications with buyer satisfaction }\end{array}$ & 0,745 & 0,000 & Rejected \\
$\begin{array}{l}\text { H3: There is a significant relationship between } \\
\text { problem-solving with buyer satisfaction }\end{array}$ & 0,769 & 0,000 & Rejected \\
\hline
\end{tabular}

The hypothesis test 1 , the correlation coefficient between the seller's commitment to customer satisfaction $r=0.667$. The positive correlation value means a commitment seller strongly associated with satisfaction of the buyer, the seller was getting good commitment increases buyer satisfaction. Generate test result $p$ value $=0.000<0: 01$, meaning that $\mathrm{Ho}=$ rejected, but accept Ha, there is a significant relationship between the seller's commitment to customer satisfaction.

The hypothesis test 2, the correlation coefficient between the seller's communications with buyer satisfaction $r=0745$. The correlation value implies a strong seller's communications related to customer satisfaction. This positive relationship implies better communication of seller, then further increase customer satisfaction. The hypothesis test using $p$-value. The calculations $\mathrm{p}$ value $=0.000<0: 01$, meaning that Ho was rejected, there is no significant relationship between the seller's communications with the buyer's satisfaction. Accepted $\mathrm{Ha}$, there is a significant relationship between the seller's communications with the buyer's satisfaction.

The hypothesis test 3 , the correlation coefficient between the settlement of the problem by the seller to the buyer's satisfaction at $r=0769$, the correlation value means solving problems by the seller was strongly correlated to customer satisfaction. The better the settlement of the problem, the more increase buyer satisfaction. Test of $p$-value $=$ $0.000<0: 01$, then Ho was rejected. Ha was accepted, there was a significant relationship between the settlement of the problem by the seller to the buyer's.

\section{CONCLUSION}

The commitment of seller was able to satisfy the buyer. The better the seller's commitment to serve the buyer, then the buyer was increasing customer satisfaction. The communication of seller was to give satisfaction to the buyer. The better the 
communication, the seller would increase the satisfaction of the buyer. The conflict handling of sellers were able to give satisfaction to the buyer. The faster and better conflict handling resolution efforts, there was increasing consumer satisfaction.

Managerial Implications. The results of studies have shown that commitment, communication and conflict handling of entrepreneurs have been able to satisfy the consumers in Cianjur. It is hoped that employers continues to be able to maintain their achievements, even increase it in the future. There should not be forgotten that the achievements of the entrepreneurs who have achieved can establish loyalty among customers in the future and most likely push the sales revenue and greater profits later in the future.

Suggestions For Further Research. The results of this study have shown that customer satisfaction was not limited only influenced by the commitment of the seller, the seller's communications and the ability of sellers in conflict handling, but there were many other factors that may affect the customer satisfaction, among others were: the attitude of the seller, product quality, product quality assurance and more which were needed attention. It was suggested that other factors may be more that could be further investigated to better satisfy consumers and promote fish feed businesses in the district of Cianjur, West Java.

\section{BIBLIOGRAPHY}

Anderson, Marcus. Liedman, Gunilla. (2013) "Managing Customer Expectations How Customer Expectation are Formed and Identified during a Project Delivery". Thesis. Department of Technology Management and Economics. Chalmers University of Technology. Goteborg. Sweden

Aijo. (1996) "The Theoretical and Philosophical Underpinnings of Relationship Marketing", European Journal of Marketing. 30 (2): 8-18

Anic, Ivan Damir. Radas, Sonja. (2006) "The Impact of Situatiiionnnal Factors on Purchasing Outcomes in the Croation Hypermarket Retailer". Ekonomski Pregled. 57 (11): 730-752 . Zagreb

Berry, (1983) Relationship Marketing American Marketing Association. Chicago

Biong and Selnes, (1995) "Relational Selling Behavior and skills in long term industrial buyer seller relationship". International Business Review. 4 (4):483

Bollen, Alex. Emes, Claire. (2008) Understanding Custmer Relationships How Important is the Personal Touch? Ipsos Mori Loyalty. https://www.ipsos-mori.com

Cannon, Joseph P. Perrault Jr, William D. (1999) "Buyer-seller relationship in business markets", Journal of Marketing Research. 36 (4) November: 439-460

Cengiz, Emrah. (2010) "Measuring Customer Satisfaction: Must or Not?”, Journal of Naval Science and Engineering. 6 (2): 76-88

Clark, (1992) Quality in Finance, Management Service, 36 (9): 24-6

Del Rio, A. Belen. Vazquez, Rodolfo. Iglesias, Victor. (2001) "The Effect of Brand on Consumer response". Journal of Consumer Marketing. 18 (5): MCB University Press. ISSN 0736-3761

Dwyer, (1987) "Developing Buyer Seller Relationship", Journal of Marketing. 51 (2) April: $11-27$ 
Fiala, R. M. Zivelova, Prokop, I. (2012) The Relationship Between Interorganizational Trust and Performance. Vol LX. Number 4. 2012. Acta Universitatis Agriculturae et Silviculturae Mendelianae Brunensis. pp 89-98. Brno. Czech Rep

Giese, Joan L. Cote, Joseph A. (2002) "Defining Consumer Satisfaction. Review. 2000 (1), Academy of Marketing Science. Washington State University Academy of Marketing Science Review. http://www.amsreview.org/articles/giese01-2000.pdf

Graf, Raoul. Roberts, Deborah. Gulot, Denis. (2011) Trust or Satisfaction in Relational Approach. The Case of Financial and High Tech-Firms. Innovative Marketing. Vol 7 , Issue 4.

Gronroos. (1994) Service Management and Marketing. Lexington Books. Lexinton.MA

Illes, Katalin. Mathews, Marthin (2015). Leadership, Trust and Communication: Building Trust in Companies Through Effective Leadership Communication. Westminster Business School. University of Westminster. in collaboration with Top Banana. Institute of Internal Communication. London. England

Kotler Philip, (1995). Marketing Management, Analisis Planning Implementation and Control, Prentice Hall

Kotler Philip, (1997) Manajemen Pemasaran, analisis Perencanaan dan Kontrol, Prenhallindo, Jakarta

Kotler Philip dan Garry Amstrong, (1995) Dasar-dasar Pemasaran, Erlangga, Jakarta

Konhauser, Andreas. (2007) "Understanding Value in B2B Buyer-Seller Relationship: Do Matching Epectations Improve Relationship Strength?”, Thesis. Auckland University of Technology

Kurtz \& Clow, (1998) Service Marketing. Will \& Sons, America

Khraim, Hamza Salim. Al-Jabaly, Sameer M. Khraim, Aymen S. (2014) The Effect of Perceived Value and Customer Satisfaction on Perceived Price Fairness of Airline Travelers in Jordan. Universal Journal of Management. 2(5): 186-196. DOI: 10.13189/ujm.2014.020502. Horizon Research Publishing. http://www.hrpub.org

Lawson, Ian. Cox, Brian. (2010) "Exceeding Expectation: The principles of outstanding leadership". The International Journal of Leadership in Public Services. 6 (1). February 2010. Pier Professional Ltd. The Work Foundation. UK. 10.5042/ijlps.2010.0269

Miall. Hugh, (2004) Conflict Transformation: A Multi-Dimensional Task. Berghof Research Center for Constructive Conflict Management - Edited version Aug 2004 (First launch Mar 2001). http//www.berghof-handbook.net

Mohanty, Manoj Kumar. (2012) Buyer Supplier Relationship in Manufacturing Industry Finding From Indian Manufacturing Sector. Business Intelligent Journal

Mohammad, Anber Abraheem Slash. Alhamadani, Shireen Yaseen Mohammad. (2011) Service Quality Perspectives and Customer Satisfaction in Commercial Banks Working in Jordan. Middle Eastern Finance and Economics. Issue 14. ISSN 14502889. Euro Journal Publishing Inc 2011. http://www.eurojournals.com/MEFE.htm

Moorman, Christine. Deshpandé, Rohit and Zaltman, Gerald (1993) "Factors Affecting Trust in Market Research Relationship", International Business Review, Vol 4 No. 4. pp. $397-418$

Morgan and Hunt, (1994) The Commitment Trus Theory of Relationship Marketing, Journal of Marketing, 58: 486-500 
Mosahab, Rahim. Mahamad, Osman. Ramayah, T. (2010) "Service Quality and Loyalty: A Test of Mediation". International Business Research. 3 (4) October 2010. ISSN 1913-9004. E-ISSN 1913-9012. www.ccsenet.org/ibr

Narayandas, Das \& V. Rangan, Kasturi. (2004) "Building and Sustaining Buyer Seller Relationship in Mature Industrial Markets". Journal of Marketing, 68 July: 63-77

Parasuraman, Zeithaml, V.A. and Berry, L.L. (1985) "A Conceptual Model of Service Quality and Its Implication for Research". Journal of Marketing, pp. 41-50 .. (1988) "SERQUAL: a multiple item Scale for Measure Consumer Perception of Service Quality", Journal of Retailing, and Vol.49.pp.41-50

Palmatier, Robert W. (2008) Relationship Marketing. Marketing Science Institute. ISBN 0-9657114-9-8, Cambridge, Massachusetts, USA

Selnes, Fred. (1995) "Antecendents and Consequences of Truss and Satisfaction in Buyer Seller Relationship”. European Journal of Marketing. Vol. 32. No. 314. pp. 305-322

Surujlal, Jhalukpreya and Dhurup, Manilal. (2012) Establish and Maintaining Customer Relationships in Commercial Health and Fitness Centers in South Africa, International Journal of Trade, economics and Finance, 3 (1) February.

Suryanto, T. (2016) Audit Delay and Its Implication for Fraudulent Financial Reporting: A Study of Companies Listed in the Indonesian Stock Exchange. European Research Studies, Vol. 19 (1), 18.

Sumarto, Prasetyo Hadi. Purwanto, Eko. Khrisna, Dewi. (2012) Antecedents of Trust and Its Impact on Loyalty: An Empirical Study on E-Commerce's Customer in Surabaya, International Journal of Information and Communication Technology Research, Vol 2 No 2, Februari, ISSN 2223-498

Senasu, Phurituc. (2012) "The Effect of Commitment, Trust, Competence, Communication, Conflict Handling Of Relationship Quality, Customer Satisfaction, Customer Loyalty". Thesis. Department of International Business. International College. University of the Thai Chambers of Commerce. Thailand

Taleghani, Mohammad. Gilaninia, Shahram. Mousavian, Seyyed Javad. (2011) "The Role of Relationship Marketing in Customer Orientation Process in the Banking Industry with focus on Loyalty (Case Study: Banking Industry of Iran)", International Journal of Busniess and Social Science. 2 (19). (Special Issue - October 2011). Center for Promoting Ideas. USA

Tolpa, Ekaterina. (2012) Measuring Customer Expectation of Service Quality: case Airline Industry. Thesis. Department of Information and Service Economy. Aalto University Schol of Eonomics. Finland

Wang, Weihong. (2004) "Management of Buyer-Suplier Relationship in the Supply Chain-Case Studies of Automotives and Telecom Supply Chains". Dissertation. ISSN 1651-0216. ISBN 91-7323-088-X. Department of Infrasturcture. Kungl. Tekniska Hogskolan. Royal Institute of Technology. Stockholm. Sweden

Walz, Anna. (2009) The Definition, Creation, and Evolution of Buyer- Seller Relationships. Dissertation. Interdepartemental program in Business Administration. Lousiana State University. Lousiana. USA

Wetzels, Martin. de Ruyter, Ko. Birgelen, Marcel Van. (1998) Marketing Service Relationship: The Role of Commitment. Journal of Business \& Industrial Marketng. 13 (4/5) 1998. pp 406-423. MCB University Press. 0885-8624 https://core.ac.uk/download/fles/153/6818528.pdf 
Zeffane, Rachid. Typu, Syed A. Ryan, James C. (2011) Communication, Commitment and Trust: Exploring the Triad, International Journal of Business and Management. 6 (6) June 2011. ISSN 1833-3850. E-ISSN 1833-8119. Canadian Center of Science and Education. Canada. 